\title{
Investigation of copper metal presence in cattle fodder, milk, hair and manure in Malta
}

\author{
Hend Abeidi ${ }^{1}$, David Suda ${ }^{2}$, Everaldo Attard ${ }^{3}$, Emmanuel Sinagra ${ }^{4}$ \\ ${ }^{I}$ Department of Chemistry, Faculty of Science, University of Malta, Msida, MSD2080, hend.abeidi.16@um.edu.mt \\ ${ }^{2}$ Department of Statistics and Operation Research, Faculty of Science, University of Malta, Msida, MSD2080, \\ david.suda@um.edu.mt \\ ${ }^{3}$ Division of Rural Sciences and Food Systems, Institute of Earth Systems, University of Malta, Msida, MSD2080, \\ everaldo.attard@um.edu.mt \\ ${ }^{4}$ Department of Chemistry, Faculty of Science, University of Malta, Msida, MSD2080, \\ emmanuel.sinagra@um.edu.mt
}

\begin{abstract}
This study investigated the concentration of copper $(\mathrm{Cu})$ present during the lifecycle of cattle in Malta to determine how metals enter and exit the animal, and their impact via the food chain on the human consumer. The determination of $\mathrm{Cu}$ in 10 cows from a dairy cattle farm located in Salina, Malta was estimated by taking milk (100), hair (100), fodder (15) and manure (10) samples over 10 weeks between September and November 2016 and their Cu concentration was determined using atomic absorption spectroscopy. Conventional methods were used to prepare all these samples. $\mathrm{Cu}$ concentration in milk samples showed high levels $(0.02$ to $0.07 \mathrm{mg} / \mathrm{L})$ which is higher than the maximum level recommended $(0.01 \mathrm{mg} / \mathrm{L})$ by FAO and WHO. $\mathrm{Cu}$ concentration was significantly higher in summer than in autumn. However, hair samples results $(3.04-6.88 \mathrm{mg} / \mathrm{kg})$ did not provide a clear impact by season. The concentration of $\mathrm{Cu}$ in different fodder types varied significantly $(1.08-16.06 \mathrm{mg} / \mathrm{Kg})$. Manure $\mathrm{Cu}$ concentrations ranged from 10.70 to $16.63 \mathrm{mg} / \mathrm{kg}$ but there were no distinctions between weeks or seasons. Considering the discrepancy of copper concentrations at inputs (feed) and outputs (manure, hair, milk) for a dairy cow, it can be concluded that there are other factors contributing to the copper concentration within the cow system.
\end{abstract}

Keywords:copper, seasons, dairy, heavy metals; toxicity, atomic absorptionspectrophotometry. DOI : doi.org/10.46617/icbe6001

\section{1) Introduction}

Heavy metals are known to be highly reactive and can be toxic even at low concentrations [1]. Although naturally occurring in the environment, anthropogenic activities, such as mining, smelting, transportation, military operations, industrial manufacturing and agricultural activities, result in the accumulation of pollutants in the environment. A typical example is the release of heavy metals from pesticides and fertilizer, leading to the contamination of the abiotic environment. These metals are transferred from the abiotic environment to the biotic ecosystems, with a build up along food webs leading to the consequential accumulation and toxicity in humans [2]. Environmental pollutants, including heavy metals, may reach target organs in humans both by ingestion[3] and by inhalation [4]. Heavy metals most commonly found to contaminate sites are lead $(\mathrm{Pb})$, chromium $(\mathrm{Cr})$, arsenic $(\mathrm{As})$, zinc $(\mathrm{Zn})$, cadmium $(\mathrm{Cd})$, copper $(\mathrm{Cu})$, mercury $(\mathrm{Hg})$, and nickel $(\mathrm{Ni})$.

The fate of heavy metals within a food chain is complex, which involves their movement through various different matrices and biological systems. Typically, the passage of heavy metals from 
milk to humans involves a series of passages between different abiotic and biotic media. Some studies have raised concerns about heavy metal contamination of irrigation water used for fodder crop cultivation, pesticides and fertilizers, drinking water for cows, atmospheric pollution, amongst others[5-6-7].These all lead to the accumulation of these metals in the cow's tissues [89] and hairs [10], a proportion of which may then be removed in urine, faeces, other excreta and milk[11]. In certain instances, soil is contaminated with heavy metals when it is amended with manure [12-13].

The copper status of dairy cows depends on various factors. Copper intake may be through fodder, water and environmental pollution. However, even though copper may be present in the diet, minerals such as Fe, Mo and S, may affect the uptake of copper by the cow. A low copper intake may result in elevated plasma copper and low copper content in milk [14]. Copper intoxication is emerging concern in dairy cows [15]. In fact, copper also alters lipid metabolism in dairy cows. In a study by Engle and coworkers a high copper dietary intake resulted in a decrease in polyunsaturated fatty acids in milk [16].

The aim of this study was to understand fate of copperwithin the dairy food chain, under intensive production in Malta, and also was to understand more about the complex pollution system under a pilot dairy setup. The final consumer within this food chain is the human.

\section{2) Materials and Methods}

\section{Reagents and glassware}

Ultrapure water(18 $\Omega$ ) was used throughout the experimental procedure, using an Elga Purelab Classic purification system (Elga,UK).All reagents used were of an ultra-trace analysis grade. Hydrochloric acid, nitric acid and hydrogen peroxide were purchased from Fisher chemical (UK), and acetone and Triton X-100 from BDH (UK). A standard solution of copper was prepared by the dilution of certified standard solutions for AAS (1000 ppm) from(Monoelement, Indian).

All glassware and polyethylene material used were previously treated for at least $24 \mathrm{hrs}$ in $10 \%$ nitric acid and rinsed with distilled water and then with ultrapure water, prior to use.

\section{Sample collection}

The samples were collected from a dairy cattle farm located in Salina, Malta. Ten cows (age from 2 to 6 years) were selected randomly from the herd representing the dairy population of this farm.

Milk and hair samples were collected from these ten cows, once a week over a period of 10 weeks starting from September 2016 until November 2016. A total of 100 milk samples and 100 hair samples were collected for analysis. Approximately $30 \mathrm{ml}$ milk samples were collected in polyethylene containers immediately from individual dairy cows. The samples were frozen immediately and stored until further analysis.Containers of each sample were put in and frozen until they were ready to be prepared for analysis. Approximately $1 \mathrm{~g}$ hair samples were taken from the tails of individual dairy cows and stored separately in polyethylene bags.Over the same time, 15 fodder samples were collected once a week from different feed sources (table2) on the farm. The fodder samples were taken and stored in polyethylene bags. Two manure samples were collected for every fortnight period, over the same time span. The samples were placed in 
polythene bags, transferred to the laboratory and dried in an oven at $75 \pm 5{ }^{\circ} \mathrm{C}$ [17]. The dried manure samples were stored separately in polyethylene bags.

\section{Sample preparation}

Milk samples were thawed and subsequently $3 \mathrm{ml}$ were prepared for the digestion process. Prior to digestion, the hair samples were cut into approximately $0.5 \mathrm{~cm}$ pieces and mixed to allow a representative subsample of the cow's hair. The sample was then washed with 5\% Triton X-100. These were then rinsed with distilled water and subsequently with ultrapure water. The samples were then rinsed three times with acetone [17-18-19], then dried in an oven at $75 \pm 5^{\circ} \mathrm{C} .0 .2 \mathrm{~g}$ of hair were taken from the dried sample for the digestion process. Fodder samples (Maltese hay and imported hay) were washed with ultra-pure water and dried at $105^{\circ} \mathrm{C}$ in an oven. All the fodder samples (Maltese hay, imported hay, pellets and mixed seeds) were ground into a powder and passed through a $0.02 \mathrm{~mm}$ sieve. $0.2 \mathrm{~g}$ subsamples of the dried feeds and manure were weighed and then subjected to digestion.

\section{Sample digestion}

$3 \mathrm{ml}$ of each milk sample and $0.2 \mathrm{~g}$ of each hair, fodder and manure sample were transferred to Pyrex beakers. 5-10 $\mathrm{ml}$ of concentrated $\mathrm{HNO}_{3}$ were added to the beakers, which were subsequently covered with a watch glass. The beakers were placed on an electric hot plate $70-$ $80^{\circ} \mathrm{C}$ for $1-2$ hours. Each digestate was then treated with additional $5 \mathrm{ml}$ concentrated $\mathrm{HNO}_{3}$ and a few drops of $\mathrm{H}_{2} \mathrm{O}_{2}$ and heated on a hot plate at about $80^{\circ} \mathrm{C}$ for another 1-2 hours until the colour of the digestion solution was a clear transparent yellow. When the resultant solutions cooled to room temperature, they were diluted up to a volume of $25 \mathrm{ml}$ in volumetric flasks with ultrapure water [17].

\section{Copper concentration determination}

The concentration of copper was determined using a high-resolution continuum source atomic absorption spectrometer (contrAA 700, Analytik Jena AG,Germany) and a calibration curve obtained from the standard solution $(0.04,0.1,0.2,0.3$ and $0.4 \mathrm{ppm})$, the AAS parameters used are shown in table 1.

Table 1 Measurement conditions for AAS

\begin{tabular}{ccccc}
\hline Element & Line & Wave length(nm) & $\begin{array}{c}\text { Oxidant (air) } \\
\left(\mathrm{Kg} / \mathrm{cm}^{2}\right)\end{array}$ & $\begin{array}{c}\text { Fuel (acetylene) } \\
\left(\mathrm{Kg} / \mathrm{cm}^{2}\right)\end{array}$ \\
\hline $\mathrm{Cu}$ & $\mathrm{Cu} 324$ & 324.754 & 1.6 & 0.2 \\
\hline
\end{tabular}

\section{Data Analysis}

The data for copper results in milk and hair for each cow were grouped into 5 fortnight period means. The data for fodder was grouped according to source and the data for manure was grouped according to same aforementioned fortnight periods. The Friedman test with Bonferroni post-hoc tests were conducted on milk and hair samples. The Kruskal Wallis test with Bonferroni post-hoc tests were conducted on fodder and manure. For fodder, milk, hair and manure, means and standard deviations for the relevant subcategories are given. Descriptive statistics and relevant statistical tests were all conducted using IBM SPSS Version 25. 


\section{3) Results and discussion}

In livestock, copper is an essential microelement that is required to maintain health and immunity. Specifically, it is required for thyroid function, production and reproduction [20]. Cows with copper deficiency are susceptible to growth impairment, anemia, reproductive problems, bone fragility and diarrhea. This is typical of grazing animals, as the copper intake cannot be estimated [21]. However, high $\mathrm{Ca}, \mathrm{Zn}$ and Fe dietary intake may lead to a decrease in copper absorption. Copper intoxication can also occur from feed formulation errors. Toxicity may be exhibited as intravascular haemolysis and methaemyoglobinaemia, susceptibility to secondary infections and debilitations, and poor milk production and morbidity [22]. Other studies have shown that copper can cause subclinical intoxication. Although in Malta, signs of copper toxicity are rarely encountered in cows, this issue should not be underestimated, especially in cases where producers are rearing cows and sheep. In most cases, sheep are more likely to respond to copper toxicosis than cows[23]. Other causes of copper intoxication can occur in areas contaminated with heavy metals industrial emission. In a study by Skalicka, Korenekova and Nad on the determination of copper levels in bovine situated $5.5 \mathrm{~km}$ from a metallurgical plant, it was found that contaminated pasture contributed to higher mean $\mathrm{Cu}$ level in cow tissue samples [24].

Feeds

In this present study a number of individual feeds and fodders were analysed individually (Table 2).It was observed that the main copper contributor is the special dairy concentrate with a value of $16.06 \mathrm{mg} / \mathrm{kg}$, and mixed seeds the least with a value of $1.08 \pm 0.07 \mathrm{mg} / \mathrm{kg}$. The former, however, only contributed to $19.7 \%$ of the total ration. Taking the ration composition as quoted by Agius and coworkers [25], the total copper composition of the ration in this study is 6.18 $\mathrm{mg} / \mathrm{kg}$ (Table 3).The dietary copper concentration should be around $15.70 \mathrm{mg} / \mathrm{kg}$ of ration [26].Several studies have shown feed copper concentrations ranging between 0.3 and 141.4 $\mathrm{mg} / \mathrm{kg}$ [27-28-29]. A cow that consumes between $9-18 \mathrm{~kg}$ of ration, the copper daily intake would be around $56-111 \mathrm{mg}$. For a $650-\mathrm{kg}$ cow, the estimated dietary copper requirement is $313 \mathrm{mg} /$ day [26]. This shows that the local cows are not receiving the optimum dietary copper intake. However, one should take into account also intake of copper from other sources. It is likely that from this source, copper intoxication is not an issue. In a study, a copper concentration of $400-500 \mathrm{mg} / \mathrm{kg}$ of the whole ration resulted in morbidity and mortality in dairy [22]. Chronic copper intoxication can occur at concentrations higher than $12 \mathrm{mg}$ of $\mathrm{Cu} / \mathrm{kg}$ of body mass per day [30].

Table 2. The Cu content for different fodder types $(\mathrm{mg} / \mathrm{kg})$

\begin{tabular}{lccccccc}
\hline & $\begin{array}{c}\text { Imported } \\
\text { hay }\end{array}$ & \multicolumn{2}{c}{ Maltese hay Mixed corn Small pellets Large pellets } & Mixed seeds & Dairy pellets \\
\hline $\mathrm{N}($ Cases $)$ & 3 & 3 & 2 & 2 & 2 & 2 & 1 \\
\hline Mean \pm SD & $4.93 \pm 0.751$ & $3.73 \pm 0.224$ & $9.81 \pm 0.774$ & $7.33 \pm 0.837$ & $2.83 \pm 0.844$ & $1.08 \pm 0.069^{\dagger}$ & $16.06^{\mathrm{a}}$
\end{tabular}

${ }^{\dagger}$ statistically different from other levels at $p<0.1,{ }^{a}$ only based on a single observation and not included in the analysis 
Table3. A typical ration composition [25] and the contribution of different feeds and fodder to the copper concentration in the ration.

\begin{tabular}{lcc}
\hline & $\% \mathrm{DM}$ & $\begin{array}{c}\text { Mg Cu per kg } \\
\text { ration }\end{array}$ \\
\hline Imported Hay & 21.37 & 1.054 \\
Straw(Local) & 5.79 & 0.216 \\
Crushed Maize/Mixed seeds & 7.54 & 0.458 \\
Normal dairy Pellets & 45.6 & 1.290 \\
Special dairy Pellets & 19.7 & 3.164 \\
\hline
\end{tabular}

Milk

As a microelement, copper is found in relatively small amounts in milk [31]. The copper content of milk as recommended by the National Research Council is $0.15-0.20 \mathrm{mg} / \mathrm{L}$ of milk [26]. In this present study, most values obtained for copper concentration in milk $(0.02-0.06 \mathrm{mg} / \mathrm{L})$ were lower than this recommended (Table 4),particularly in later (autumn) periods. Pilarczyk and coworkers [32], in a study on Simmental and Holstein-Friesian cows from an organic farm, found particularly low $\mathrm{Cu}$ concentrations amounting to 0.04 and $0.05 \mathrm{mg} / \mathrm{L}$, respectively, indicating the deficiency of this element in animals and thus in the environment and feed, typical of extensive systems. Several studies show copper concentrations below $0.07 \mathrm{mg} / \mathrm{L}$ [33-34-35]. In a local study [36], the $\mathrm{Cu}$ milk content for cows was $0.23 \pm 0.13 \mathrm{mg} / \mathrm{L}$ which goes in accordance with the findings of Bresci and coworkers (0.31-0.32 mg/L)[37]. Al-Wabel found a level of $1.88 \mathrm{mg}$ copper per litre of milk [38]. In another study, the level copper in milk from cows fed on a conventional diet and hydroponic fodder [25], the mean $\mathrm{Cu}$ contents were up to $0.75 \mathrm{mg} / \mathrm{L}$, during a 4-week trial. The values found agree with results of Meshref who found $\mathrm{Cu}$ values equal to $0.6 \mathrm{mg} / \mathrm{kg}$ [39]. Moreover, Bilandžic reported $\mathrm{Cu}$ concentrations ranging from 0.10 to $0.90 \mathrm{mg} / \mathrm{L}[40]$.

\section{Hair}

$\mathrm{Cu}$ contributes to the formation of keratin and melanin, of which there are two types; eumelanin, giving the brown-black coloration and pheomelanin, giving the yellow-red coloration [41]. There is an initial oxidation reaction between the copper-protein enzyme tyrosinase and tyrosine [42]. In present study (see Table 4 for full results), the mean copper concentration in hairs was 4.80 $\mathrm{mg} / \mathrm{kg}$, with significant period-to-period variation. This is much lower than those quoted by Dorn and coworkers, i.e. $7.33-7.74 \mathrm{mg} / \mathrm{kg}$ [43].

Table 4. The $\mathrm{Cu}$ content for milk $(\mathrm{mg} / \mathrm{L})$, hair and manure $(\mathrm{mg} / \mathrm{kg})$

\begin{tabular}{llllll}
\hline Period & 1 & 2 & 3 & 4 & 5 \\
\hline Milk & $0.07 \pm 0.05^{* * *}$ & $0.06 \pm 0.02^{* * *}$ & $0.04 \pm 0.01$ & $0.02 \pm 0.02^{* * *}$ & $0.02 \pm 0.01^{* * *}$ \\
Hair & $3.04 \pm 1.21^{* * *}$ & $6.88 \pm 4.43^{* * *}$ & $5.83 \pm 2.34^{* * *}$ & $4.29 \pm 0.84^{\dagger}$ & $3.98 \pm 2.19^{*}$ \\
Manure & $12.20 \pm 2.77$ & $10.70 \pm 1.98$ & $16.63 \pm 7.64$ & $10.49 \pm 3.81$ & $15.06 \pm 1.16$ \\
\hline \multicolumn{5}{r}{ statistically different from other levels at $p<0.001^{* * *}, p<0.01^{* *}, p<0.05^{*}, p<0.1^{\dagger}$} \\
\multicolumn{5}{c}{52}
\end{tabular}




\section{Manure}

The accumulation of copper in manure may contribute to copper passed on to ground water and soil which then can become available to crops and fodder crops [44]. Accumulation of copper in soil is much higher with dairy manure amendment than with manure from other farm animals [45]. Cows eliminate excess copper into faeces (manure). In most cases, cow manure is used as an organic fertilizer in situations where soil amendment is deemed necessary, hence enriching the soil with important minerals. In fact, in a study by Moscuzza and coworkers, it was deduced that forage was enriched with micronutrients when manure was used during the cultivation of the fodder crops [46]. Several studies have shown manure copper concentrations ranging between 31.80 and $1726.30 \mathrm{mg} / \mathrm{kg}$ [27-28-29]. In this present study, the copper concentration of manure reached a maximum of $16.63 \pm 7.637 \mathrm{mg} / \mathrm{kg}$ (Table 4), which is on the lower end of the range, quoted in other studies. A cow produces approximately $29.5 \mathrm{~kg}$ of manure daily. The copper lost in faeces by a cow is $383.972 \mathrm{mg}$ daily (Figure 1).

In conclusion, Figure 1 provides an overview of the copper contribution of feed, manure, hair and milk as input and output parameters within the cow system[47,48]. It can be observed that the input of copper from feed does not tally to the output of copper through manure, hair and milk. A high copper concentration was expressed in manure as compared to all other input/output parameters. This may be due to the copper entering the system through other inputs parameters and/or copper accumulation and release from outputs. This provides the basis for further research taking into account more inputs, such as drinking water and atmospheric pollution and other outputs such as urine in liquid manure.

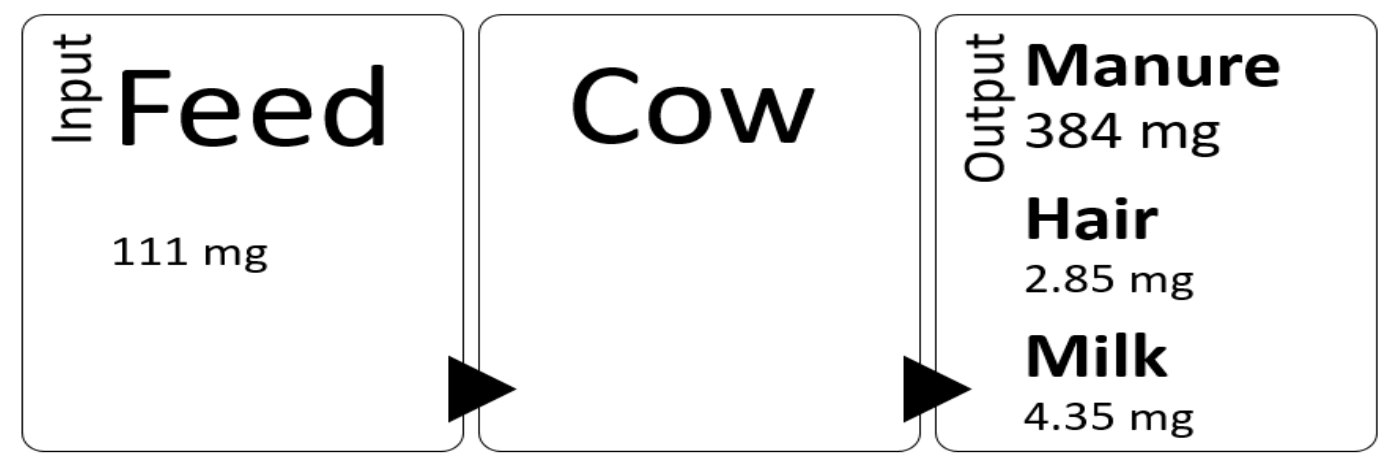

Figure 1. The input and output parameters considered in this study, and the copper contribution of each parameter on a daily basis.

\section{4) References}

[1] Järup, L.,2003. Hazards of heavy metal contamination. British Medical Bulletin, 68(1), 167-182. doi:https://doi.org/10.1093/bmb/ldg032.

[2] De Vries, W., Groenenberg, J. E., Lofts, S., Tipping, E.and Posch, M., 2013. Critical loads of heavy metals for soils. Heavy metals in soils (pp. 211-2) Springer37.

[3] Khan, S., Cao, Q., Zheng, Y., Huang, Y.and Zhu, Y., 2008. Health risks of heavy metals in contaminated soils and food crops irrigated with wastewater in beijing, china. Environmental Pollution, 152(3), 686-692.

[4] Brauer, M., Hoek, G., Van Vliet, P., Meliefste, K., Fischer, P. H., Wijga, A. and. Kerkhof, M., 2002. Air pollution from traffic and the development of respiratory infections and asthmatic and allergic symptoms in children. American Journal of Respiratory and Critical Care Medicine, 166(8), 1092-1098.

[5] Javed, I., Jan, I., Muhammad, F., Khan, M. Z., Aslam, B.and Sultan, J. I., 2009. Heavy metal residues in the milk of cattle and goats during winter season. Bulletin of Environmental Contamination and Toxicology, 82(5), 616-620. 


\section{Proceeding of $6^{\text {th }}$ nternational Conference of Biotechnology, Environment and Engineering Sciences (ICBEI) 28 - 29 December 2019, Alexandria-Egypt}

[6] Nazir, R., Khan, M., Masab, M., Rehman, H. U., Rauf, N. U., Shahab, S. and Rafeeq, M., 2015. Accumulation of heavy metals ( $\mathrm{Ni}, \mathrm{Cu}, \mathrm{Cd}, \mathrm{Cr}, \mathrm{Pb}, \mathrm{Zn}, \mathrm{Fe}$ ) in the soil, water and plants and analysis of physico-chemical parameters of soil and water collected from Tanda Dam Kohat. Journal of Pharmaceutical Sciences and Research, 7(3), 89.

[7] Rajaganapathy, V., Xavier, F., Sreekumar, D.and Mandal, P. K., 2011. Heavy metal contamination in soil, water and fodder and their presence in livestock and products: a review. Journal of Environmental Science and Technology, 4(3), $234-249$.

[8] Jukna, C., Jukna, V.and Siugzdaite, J., 2006. Determination of heavy metals in viscera and muscles of cattle. Bulgarian Journal of Veterinary Medicine, 9(1), 35-41.

[9] Nwude, D. O., Okoye, P. A. C. and Babayemi, J. O., 2011. Assessment of heavy metal concentrations in the liver of cattle slaughter during three different seasons. Res J Envirom Sci, 5(3), 288-294.

[10]Patra, R. C., Swarup, D., Naresh, R., Kumar, P., Nandi, D., Shekhar, P. and Ali, S. L.,2007. Tail hair as an indicator of environmental exposure of cows to lead and cadmium in different industrial areas. Ecotoxicology and Environmental Safety, 66(1), 127-131.

[11] Li, J., Xu, Y., Wang, L. and Li, F., 2019. Heavy metal occurrence and risk assessment in dairy feeds and manures from the typical intensive dairy farms in China. Environmental Science and Pollution Research, 26(7), 6348-6358.

[12] Sinclair, L. A., Hart, K. J., Johnson, D. and Mackenzie, A. M.,2013. Effect of inorganic or organic copper fed without or with added sulfur and molybdenum on the performance, indicators of copper status, and hepatic mRNA in dairy cows. Journal of dairy science, 96(7), 4355-4367.

[13] Sinclair, L. A., Johnson, D., Wilson, S. and Mackenzie, A. M., 2017. Added dietary sulfur and molybdenum has a greater influence on hepatic copper concentration, intake, and performance in Holstein-Friesian dairy cows offered a grass silagerather than corn silage-based diet. Journal of dairy science, 100(6), 4365-4376.

[14] Morales, M. S., Palmquist, D. L. and Weiss, W. P., 2000. Effects of fat source and copper on unsaturation of blood and milk triacylglycerol fatty acids in Holstein and Jersey cows. Journal of Dairy Science, 83(9), 2105-2111.

[15] Bidewell, C. and Livesey, C., 2002. Copper poisoning: an emerging disease in dairy cattle. State Veterinary Journal, 12(2), 16-19.

[16] Engle, T. E., Fellner, V. and Spears, J. W., 2001. Copper status, serum cholesterol, and milk fatty acid profile in Holstein cows fed varying concentrations of copper. Journal of Dairy Science, 84(10), 2308-2313.

[17]Afridi, H. I., Kazi, T. G., Jamali, M. K., Kazi, G. H., Arain, M. B., Jalbani, N. and Shar, G. Q.,2006. Analysis of heavy metals in scalp hair samples of hypertensive patients by conventional and microwave digestion methods. Spectroscopy Letters, 39(2), 203-214.

[18]Assarian, G. S. and Oberleas, D., 1977. Effect of washing procedures on trace-element content of hair. Clinical Chemistry, 23(9), 1771-1772.

[19]Salmela, S., Vuori, E. and Kilpiö, J. O., 1981. The effect of washing procedures on trace element content of human hair. Analytica Chimica Acta, 125, 131-137.

[20] Yatoo, M. I., Saxena, A., Deepa, P. M., Habeab, B. P., Devi, S., Jatav, R. S. and Dimri, U., 2013. Role of trace elements in animals: a review. Veterinary world, 6(12), 963. doi:http://dx.doi.org.ejournals.um.edu.mt/10.14202/vetworld.2013.963-967.

[21] Khan, Z. I., Ashraf, M., Al-qurainy, F., Ahmad, K., Gondal, S.and Fardous, A., 2011. Studies on the transfer of copper from soil to pastures at different sampling periods: A case study of a semiarid region (sargodha) in pakistan. Biological Trace Element Research, 141(1-3), 126-30.

[22]Perrin, D. J., Schiefer, H. B. and Blakley, B. R., 1990. Chronic copper toxicity in a dairy herd. The Canadian Veterinary Journal, 31(9), 629.

[23]Christodoulopoulos, G. and Roubies, N.,2007. Diagnosis and treatment of copper poisoning caused by accidental feeding on poultry litter in a sheep flock. Australian Veterinary Journal, 85(11), 451-453. doi:10.1111/j.1751-0813.2007.00186.

[24]Skalicka, M., Korenekova, B. and Nad', P., 2005. Copper in livestock from polluted area. Bulletin of Environmental Contamination and Toxicology, 74(4), 740-744.

[25]Agius, A., Pastorelli, G.and Attard, E.,2019. Cows fed hydroponic fodder and conventional diet: effects on milk quality. Archives Animal Breeding, 62(2), 517-525.

[26] National Research Council. (2001). Nutrient Requirements of Dairy Cattle. Seventh Revised. https://www.nap.edu/read/9825/chapter/8\#133

[27]Nicholson FA, Chambers BJ, Williams JR, Unwin RJ.,1999. Heavy metal contents of livestock feeds and animal manures in England and Wales. Bioresource Technology,70(1):23-31.

[28]Cang L, Wang YJ, Zhou DM. and Dong YH.,2004. Heavy metals pollution in poultry and livestock feeds and manures under intensive farming in Jiangsu Province, China. Journal of Environmental Sciences; 16(3):371-4.

[29]Xiong, X., Yanxia, L., Wei, L., Chunye, L., Wei, H. and Ming, Y., 2010. Copper content in animal manures and potential risk of soil copper pollution with animal manure use in agriculture. Resources, Conservation and Recycling, 54(11), 985-990.

[30]Gummow, B., 1996. Experimentally induced chronic copper toxicity in cattle. Onderstepoort Journal of Veterinary Research, 63:277-288.

[31]Gaucheron, F., 2011. Milk and Dairy Products: A Unique Micronutrient Combination, Journal of the American College of Nutrition, 30 (5), 400S-409S.

[32]Pilarczyk, R., Wójcik, J., Czerniak, P., Sablik, P., Pilarczyk, B., and Tomza-Marciniak, A., 2013. Concentrations of toxic heavy metals and trace elements in raw milk of Simmental and trace elements in raw milk of Simmental and HolsteinFriesian cows from organic farm, Environ. Monit. Assess., 185, 8383-8392. 


\section{Proceeding of $6^{\text {th }}$ nternational Conference of Biotechnology, Environment and Engineering Sciences (ICBEI) 28 - 29 December 2019, Alexandria-Egypt}

[33]Sola-Larrañaga, C. and Navarro-Blasco, I., 2009. Chemometric analysis of minerals and trace elements in raw cow milk from the community of navarra, spain. FoodChemistry, 112(1), 189-196.

[34]Perween, R., Bhutto, A., Ara, D., Shaukat, S. S. and Haq, Q., 2013. Elucidation of physico-chemical characteristics and mycoflora of bovine milk available in selected area of karachi, pakistan. Journal of Applied Science \& Environmental Management, 17(2), 259-265.

[35]Dobrzanski, Z., Kolacz, R., Górecka, H., Chojnacka, K. and Bartkowiak, A., 2005. The content of microelements and trace elements in raw milk from cows in the silesian region. Polish Journal of Environmental Studies, 14(5), 685-689.

[36]Spiteri, R. and Attard, E., 2017. Determination of major and minor elements in maltese sheep, goat and cow milk using microwave plasma-atomic emission spectrophotometry. J. Agr. Sci, 9, 43-50.

[37]Brescia, M. A., Caldarola, V., Buccolieri, G., Dell' Atti, A. and Sacco, A., 2003. Chemometric Determination of the Geographical Origin of Cow Milk using ICP-OES Data and Isotopic Rations: A Preliminary Study. Italian Journal of Food Science, 15(329), 3.

[38]Al-Wabel, N. A., 2008. Mineral contents of milk of cattle, camels, goats and sheep in the central region of Saudi Arabia. Asian Journal of Biochemistry, 3(6), 373-375.

[37]Meshref, A. M. S., Moselhy, W. A., El-Houda, N. and Hassan, Y., 2014. Heavy metals and trace elements levels in milk and milk products, J. Food Meas. Charact., 8, 381-388.

[40]Bilandži'c, N., Doki'c, M., Sedak, M., Solomun, B., Varenina, I., Kneževi'c, Z. and Beni'c, M.,2011. Trace element levels in raw milk from northern and southern regions of Croatia, Food Chem, 127, 63-66.

[41]Tomlinson, D. J., Mülling, C. H. and Fakler, T. M., 2004. Invited review: formation of keratins in the bovine claw: roles of hormones, minerals, and vitamins in functional claw integrity. Journal of dairy science, 87(4), 797-809.

[42]Seo, K., Mohanty, T. R., Choi, T. and Hwang, I., 2007. Biology of epidermal and hair pigmentation in cattle: a mini-review. Veterinary dermatology, 18(6), 392-400.

[43]Dorn, C. R., Phillips, P. E., Pierce, J. O. and Chase, G. R.,1974. Cadmium, copper, lead and zinc in bovine hair in the new lead belt of Missouri. Bulletin of environmental contamination and toxicology, 12(5), 626-632.

[44]Arnesen, A. K. M. and Singh, B. R., 1998. Plant uptake and DTPA-extractability of Cd, Cu, Ni and Zn in a Norwegian alum shale soil as affected by previous addition of dairy and pig manures and peat. Canadian Journal of Soil Science, 78(3), 531539.

[45]Brock, E. H., Ketterings, Q. M. and McBride, M., 2006. Copper and zinc accumulation in poultry and dairy manure-amended fields. Soil Science, 171(5), 388-399.

[46] Moscuzza, C. H., Pérez-Carrera, A. L., Volpedo, A. V. and Fernández-Cirelli, A., 2012. Forage enrichment with copper and zinc in beef grazing systems in Argentina. Journal of Geochemical Exploration, 121(0), 25-29.

[47]Udo, H. M. J.Veenman, H. And Zonen BV., 1978. Hair coat characteristics in Friesian heifers in the Netherlands and Kenya. [48] McDowell, R. E., Lee, D. H., McMullan, H. W., Fohrman, M. H. and Swett, W. W. 1954. Body weights, body measurements, and surface area of Jersey and Sindhi-Jersey (F1) crossbred females. Journal of Dairy Science, 37(12), 14201428.

https://www.do1.org/10.46617/1cbe6001 